\title{
Jael's Identities
}

Having now examined Jael from the perspective of gender, we turn in this final chapter of Part IV to her representative role as a member of the Kenites. While a number of biblical texts identify this group as the nation's enemies, others depict a special relationship between them and Israel. As we work through these texts, our guiding question will be: What does the case of the Kenites reveal paradigmatically about Israel's ethnogenesis and the formation of biblical literature?

\section{THE KENITES' SOLIDARITY WITH ISRAEL}

At the beginning of our investigation, we saw that the episode in which Jael assassinates the Canaanite commander appears to have been appended to the prose account in Judges 4 . Connected to this episode is a statement that appears earlier in the narration:

Now Heber the Kenite had separated from the Kenites [lit. qayin or "Cain"] from the descendants of Hobab, Moses's father-in-law - and had pitched his tent at Elon-Bezaanannim, which is near Kedesh. Judg. 4:I I

This statement interrupts the flow of the story and was likely not part of its original iteration. To understand why a scribe would have added it, we need to consider the introduction to the Jael episode:

But Sisera fled by foot to the tent of Jael, the wife of Heber the Kenite, because there was an alliance [lit. peace] between King Jabin of Hazor and the house of Heber the Kenite. Judg. 4:17 
This introduction begs a basic question for the readers: In making an alliance with Israel's enemy, was the house of Heber representative of, or an exception among, the Kenites? The insertion of 4:II responds by declaring that Heber had "separated from the Kenites" and pitched his tent apart from them. Accordingly, Sisera's flight to Heber's camp doesn't mean that the Kenites as a whole were on the side of Sisera and Jabin. ${ }^{\mathrm{I}}$

Heber's political associations were not representative of the Kenite population corporately, and in fact they had caused a division within Heber's own household. The name Heber means "friend" or "ally" in most Semitic languages; in Akkadian, the verb habarum refers to the act of leaving one's house (i.e., moving to a new political domain). ${ }^{2}$ Yet contrary to Heber's intentions, the alliance he makes with the Canaanites ultimately works in Israel's favor. As Israel routs the enemy forces, Sisera seeks refuge in Heber's camp, and it is there that this Canaanite general meets his violent death at the hands of Heber's own wife. ${ }^{3}$ In executing the general with remarkable finesse and guile, Jael openly opposes her deviant husband and tangibly reaffirms the Kenites' collective and enduring loyalty to Israel.

Jael's bravery illustrates, according to these scribes, the solidarity that had long defined the relationship between the Kenites and Israel. In 4:I I, an interjected clause describes the Kenites as the "descendants of Hobab, Moses's father-in-law." The first chapter of the book contains a verse with similar information:

The Kenite descendants [lit. the descendants of Keni]], ${ }^{4}$ Moses's father-in-law, went up from the City of Palms with the people of Judah into the wilderness of Judah that is in the Negeb of Arad. They went and settled among the people. ${ }^{5}$ Judg. I:I 6

${ }^{I}$ If the second half of 4:I 7 ("because there was an alliance between King Jabin of Hazor and the house of Heber the Kenite") is supplementary, it may represent a simultaneous or earlier attempt to make Heber's clan an exception among the Kenites.

2 Abraham Malamat, "Mari and the Bible," Journal of the American Oriental Society, 83 (I962), I43-I50, compared the word to the Mari hibrum, a political association or "nomadic community." On the Mari evidence, see Daniel E. Fleming, Democracy's Ancient Ancestors (New York: Cambridge University Press, 2004), 97-IO2, 23 I.

3 A rabbinic source (Ex. Rab. 4.2) links Moses's flight to the tent of Jethro, on the one hand, and the flight of Sisera to the tent of Jael, on the other.

${ }^{4}$ Most of the Greek versions supply the name Hobab, whereas the rabbis concluded that Keni is one of the many names for Moses's father-in-law and the eponymous ancestor of the Kenites (see, e.g., Mek. Rab. Ish. I:I).

5 Some versions have "among the Amalekites" in place of "among the people," anticipating Saul's engagement with both populations in I Samuel I 5 . 
Within the context of Judges, the line anticipates the material about Jael that was added to the Deborah story; as we shall see, it also represents a piece of an extended narrative that earlier scribes had produced through piecemeal insertions at key points in the exodus-conquest account. Although this narrative originally had nothing to do with the Kenites, it now serves a new purpose: Readers of the nation's story should understand that the Kenites had long been close allies. During the days of the exodus and wilderness wanderings, Moses had forged a personal bond with their eponymous ancestor, who was none other than his father-inlaw. During the conquest and settlement, the Kenites had inherited a portion of the Promised Land with the tribe of Judah. Therefore, by flouting her husband's political alliance, Jael reaffirmed the Kenites' longstanding loyalty to the nation.

In the Deborah-Barak story, we can retrace the steps scribes took as they responded to polemical attacks on the Kenites. The prose version of the story has been expanded with a new culminating scene that ingeniously admits a case of Kenite betrayal while simultaneously making it exceptional. Likewise, the song has been augmented with lengthy strophes that go even further: Jael is praised as the "wife of Heber the Kenite," without anything being said about this man's ties to the enemy. Jael's deed is offered here as both illustration and evidence of the special relationship with the Kenites. They are exemplary "friends" of Yhwh (lit. those who love him). ${ }^{6}$

\section{THE KENITES ON THE BIBLICAL LANDSCAPE}

In the book of Judges, the Kenites are descendants of Hobab, Moses's father-in-law. Describing Israel's departure from Sinai (or "the Mountain of Yhwh"), the book of Numbers presents Moses approaching Hobab with a petition that he join them as their guide through the wilderness. Yet in this account, Hobab is designated as the son of Moses's father-in-law, who here is called "Reuel the Midianite" (Num. Io:29-32). In addition to being the name of one of Esau's sons and thus a prominent figure in the Edomite genealogy (Gen. 36), ${ }^{7}$ Reuel appears in the tale of Moses's flight

${ }^{6}$ Notice how the Jael material in 5:24-30 has been directly placed before the final line about Yhwh's friends in verse $3 \mathrm{I}$.

7 The genealogy includes also Jitran (Gen. 36:26), a name that is related to Jethro. Whatever the case may be, the amplified form of this chapter likely represents an attempt to incorporate all southern populations in the lineage of Edom. The amplification likely reflects the period leading up to and after $587 \mathrm{BCE}$, when the Edomites came to control 
from Egypt, where he bears the title "the Midianite priest" (Exod. 2:I I22). The sequel to that episode is the story of the burning bush, and there he is called by yet another name: Jethro.

Over the centuries, interpreters have offered various solutions to the confusion of these three names, an issue that does not merit our attention here. What's more important for our purposes is how our texts conceive of the Kenites as descendants from the family of Moses's wife and thus related to the Midianites. Strangely, other biblical texts provide little in the way of support for a historical relationship between the Kenites and the Midianites. The reason for this fact is that the identification of the Kenites as descendants of Moses's Midianite in-laws has really little, if anything, to do with the Midianites; rather, it represents a clever scribal attempt to connect the Kenites' story to the nation's narrative by linking them to none other than the founder's own family.

The origins of the Kenites are treated in a genealogy that later scribes connected to the story of Cain and Abel (Gen. 4). The name "Cain" (qayin) and the ethnonym "Kenite" (qêynî) are closely related. ${ }^{8}$ The Semitic root is related to "forge" and "metalworker" in Arabic, Syriac, and Palmyrene. In the description of Cain's progeny, one of his descendants, named Tubal-cain, is honored as the father of metallurgy, "a smith of all kinds of bronze and iron tools" (Gen. 4:22). The genealogy also ascribes to the Kenites' ancestors a number of technological and cultural achievements. In addition to being a pioneer in agriculture, Cain builds the first city (Gen. 4:1 7; agricultural innovations indeed paved the way for urbanism), and his offspring are identified as the first nomadic herders, musicians, and smiths (Gen. 4:20-22).

In the context of Genesis, the Kenite genealogy paints these Promethean achievements in dark tones. The metallurgical innovations served, not least, the needs of warfare. (The word qayin can also mean spear.) Cain murders his brother and, as consequence, is doomed to a vagabond existence. ${ }^{9}$ Like their eponymous ancestor, the Kenites are depicted as nomads in biblical

much of the Negev, eventually even beyond Hebron (Kenizzite territory). Attempts by scholars (see n. 27 below) to use this text as a source for the reconstruction of Judah's origins are hence problematic.

${ }^{8}$ For an excellent survey of the issue, see Baruch Halpern, "Kenites" in David Noel Friedman (ed.), The Anchor Bible Dictionary, vol. 4 (New York: Doubleday, I992), I7-22.

9 The "mark of Cain," which serves somehow to protect the despised fugitive, may be compared to the grotesque appearance of many mythic smiths, like the Greek god of metallurgy Hephaestus. 
texts. The authors of Genesis may not have intended that their readers attribute these characteristics to the Kenites of their own time, since the flood destroys the antediluvian population; the flood story may have been added subsequently, however. ${ }^{\mathrm{IO}}$ Whatever the case may be, the genealogy serves the needs of the narrative, which portrays the gradual emergence of human civilization characterized by the tragic dichotomy between technological progress and a propensity for violence.

The Kenites make an appearance in the "Story of David's Rise" in the book of Samuel, which tells how the Judean king spends his early days as a warlord providing protection and robbing marauders of the wealth they had seized. Three of the regions in which he and his men roam are the Negeb of Judah, the Negeb of the Jerahmeelites, and the Negeb of the Kenites (I Sam. 27:IO). In order to win the favor of those who could make him king, David behaves like a mafioso and shares "the spoils of the enemies of Yhwh" with his people. These enemies include "the towns of the Jerahmeelites and the towns of the Kenites" (I Sam. 30:29). The next episode in this older narrative portrays David and his men moving to the Hebron, where he is made king over the federation he had created, designated "the House of Judah" (2 Sam. 2:I-4). This narrative implies that the Kenites were the enemies of the Judean population that appointed David to be their king.

I discuss these texts and the process of Judah's consolidation elsewhere. ${ }^{\text {II }}$ Many of the populations that formed the kingdom of Judah continued to play a key role in the centuries that followed, and the narrative of David's rise and reign reflects not the actual origins so much as (early) dynamics and political concerns in the kingdom after David's reign. The Kenites may, accordingly, have been a population that the historical David plundered on his way to kingship. However, the reference to them may indicate only that they were a political issue in Judah at the time when scribes were composing the account. In the latter scenario, it's noteworthy that the scribes, presumably working for the palace in Jerusalem, used a form of war commemoration when polemicizing against them. Instead of the allies of Israel and friends of Yhwh, they are remembered here as outsiders opposing the nation's hero as he used his private army to carve out a kingdom in the Judean desert. ${ }^{\mathrm{I} 2}$

to See Idan Dershowitz, "Man of the Land: Unearthing the Original Noah," Zeitschrift für alttestamentliche Wissenschaft, I28 (2016), 357-373.

II Wright, David, King of Israel, 39-45, I72-I 74 .

${ }^{12}$ Since the story of David's rise to power presents the protagonist in a rather unflattering light, as a Machiavellian ruler who stops at nothing in his quest for the throne, the 
The Bible refers frequently to many little-known population groups; as a rough-and-ready rule, one can posit that the frequency with which these populations are mentioned is indirectly related to the degree to which they were integrated and assimilated into the larger political communities of Israel and Judah. In the case of Judah, some peoples, such as the Jerahmeelites, are mentioned very rarely, and the likely reason for their low profile is that they were fully absorbed into Judah, gradually relinquishing their identity as a distinctive clan. If we hear about the Kenites more than the Jerahmeelites, it's because the Kenites either struggled longer to maintain a distinct identity, were more important as a population, and/or presented more obstacles to their integration. ${ }^{\mathrm{I}}$

The image of the Kenites as indigenous outsiders who must be subjugated is found not only in the story of David's rise to power. In the Abraham account in the book of Genesis, Yhwh makes a covenant with the patriarch, promising his offspring a vast stretch of land from Egypt to the Euphrates. This land is occupied by ten peoples whom Abraham's descendants would have to dispossess, and the Kenites are the first group in this list (Gen. I 5:I 8-2I). ${ }^{\mathrm{I}}{ }^{4}$

A more vociferous attack on the Kenites is found in the Balaam account from the book of Numbers. Balaam is hired by King Balak of Moab, together with the elders of Midian, to pronounce a curse on Israel (see the discussion in Chapter I). At the end of the account, the seer finally delivers the long-awaited imprecation, but it is directed solely at Israel's enemies, which include the Amalekites and the Kenites:

He saw Amalek and, uttering his oracle, he said:

"First among the nations is Amalek.

But its end is to perish forever."

He saw the Kenites and, uttering his oracle, he said:

"Though your abode be secure, And your nest be set among cliffs,

Yet shall [you] Cain be purged/burned,

When Assyria takes you captive."

Num. 24:20-22

mention of the Kenites as one of three populations in the Negev whom David ruthlessly plunders may be intended to cast them in a sympathetic light.

${ }^{13}$ For an exemplary study of populations in the Negev from a material-cultural perspective, see Juan Manuel Tebes, “Cerámicas 'Edomita,' 'Madianita,' y 'Negevita': ¿Indicadoras de grupos tribales en el Negev?," Antiguo Oriente, 2 (2004), 27-49.

${ }^{\mathrm{I} 4}$ For the putative Davidic dating of this text and the problems it presents, see Wright, David, King of Israel, I68-I72. 
The language plays on the consonance of Cain or Kenite (qāyin/qênî) and "your nest" (qinnekā); as noted, the name Cain/Kenite can also mean smith, which matches the fate of this population being purged/burned. It's remarkable that the curse of the Kenites is twice as long as that of the Amalekites, even though the latter are the most despised of Israel's enemies in the Bible. ${ }^{15}$

\section{FROM SAUL TO MOSES}

The association of the Kenites with the Amalekites is reflected also in I Samuel I5, which presents Saul going to war with the latter. What motivates his bellicosity is a war memory from the earliest days of the nation, when Israelite refugees were making their way from Egypt to the Promised Land. The Amalekites attacked them when they were most vulnerable, and now that Israel has finally, after many centuries, become strong, Saul intends to exact revenge on the Amalekites.

As the troops of Israel approach "the city of Amalek" and are about to wreak carnage on its inhabitants, Saul sends a message to the Kenites, who were living in their midst:

Leave! Withdraw at once from among the Amalekites, so that I may not destroy you along with them! For you showed kindness to all the Israelites when they went up from Egypt. I Sam. I 5:6

The Kenites deserve special protection because, in contrast to the Amalekites, they demonstrated hesed (loyalty, hospitality, generosity) to the Israelites when they were making their way from Egypt to Canaan.

The Pentateuch records the belligerent actions of the Amalekites after the exodus from Egypt, yet what about the Kenites and their act of hesed?

I5 Another case of biblical polemics against the Kenites might be found in the Nehemiah Memoir. A silver bowl that was found in Egypt and dates to ca. 4IO BCE bears an Aramaic votive inscription that reads: "Qainu (or Cain) son of Geshem brought an offering to Han-Ilat." This name may reflect a Kenite affiliation. The Nehemiah Memoir claims that a leader of the Arabs named Geshem took part in military coalitions that planned to attack Jerusalem and disrupt the reconstruction of Jerusalem. On this inscription, as well as the Septuagint's translation of "in the land of Goshen" in Genesis 45:10 and 46:34 as "in the land of Geshem of Arabia," see Israel Eph'al, The Ancient Arabs: Nomads on the Borders of the Fertile Crescent, 9 th- 5 th Centuries BC (Jerusalem: Magnes, I982), 2I2-2I4.

${ }^{16}$ On the basis of this passage, many modern translations emend the notice in Judges I:I $6 \mathrm{~b}$ so that the Kenites settle "with the Amalekites" instead of "with the people" ('et-ha' 'ām). According to that reading, the notice represents a polemical gloss that departs from the pro-Kenite depiction in Judges I:I6a. 
Where is that "memory" recorded? In Part I, we saw that a number of texts negotiate relations with Israel's neighbors (the Edomites, Moabites, Ammonites, and others) by reporting their responses to Israel's conventional petitions for permission to pass through their lands. Thus, in the books of Deuteronomy and Nehemiah, the Ammonites and Moabites are barred from the "congregation of Yhwh" because they failed to meet Israel with bread and water in the wilderness (Deut. 23:4-5; Neh. I $3: I-3)$. While a number of texts relate to the hospitality/belligerence displayed by the various peoples whom Israel encountered in the wilderness, we search in vain for one that describes interactions with the Kenites.

It's entirely conceivable that the authors of I Samuel I 5 used allusion to concoct an ad hoc memory that affirms the Kenites' historic loyalty to Israel. After all, the cases of Deuteronomy and Nehemiah cited above fabricate wartime memories for two other peoples - the Ammonites and the Moabites - in an effort to disqualify them from cultic rights and societal privileges, while other texts flatly contradict this memory in an effort to present these neighbors in a more favorable light.

However, in light of the connections between the Kenites and the Midianites that we observed in the figure of Moses's father-in-law, it seems more likely that the authors of the Saul account intended that their readers (re-)interpret several "Midianite" accounts as illustrations of the hesed the Kenites manifested to Israel. When Moses flees from the Egyptian court into the wilderness, the figure of Reuel, "the priest of Midian," performs exemplary hospitality by feeding him, convincing him to stay with him, and extending to him the hand of one of his seven daughters (Exod. 2:I6-22). Later, after Israel had escaped from the Egyptians and was encamped at "the Mountain of God," this same figure, now called Jethro, travels to meet his son-in-law (Exod. I 8). The account of their warm reunion comes directly on the heels of the story of the Amalekites attacking Israel. Along with Aaron and the elders of Israel, Jethro and Moses enjoy a covenantal meal, with Jethro bringing burnt offerings and sacrifices to God. In what appears to be a supplementary section (vv. I3-26), Jethro advises Moses to establish a system of judges to alleviate the burden of adjudicating Israel's disputes. ${ }^{17}$

${ }^{17}$ The placement of the Jethro account in Exodus I 8 is a problem: Israel doesn't arrive at "the mountain" until the next chapter. Martin Buber argued that the redactor wished to embellish the Kenites' hospitality by positioning the episode immediately after the description of the Amalekites' military assault on the Israelite refugees in Exodus I7; 
It's important to distinguish here between what the authors of I Samuel I 5 intended their readers to understand and the interpretation of these Pentateuchal texts on their own terms. The latter do not refer to Moses's in-laws as "Kenites," and the Kenites likely had little, if any, historical relationship to the Midianites. When critical scholars today use these texts to reconstruct the history of Israelite-Kenite relations, they are simply following the suggestion of the biblical scribes and harmonizing competing texts. To study Israel's ethnogenesis in a careful manner, we must appreciate the political dimensions of the scribal discourse in our sources. The participants in this discourse were less concerned to provide an accurate account of the past; instead, they were answering such basic questions as: Who belongs to the people of Israel? Who are our friends? Who are our foes? They routinely addressed these questions by creating new texts and reworking older ones as a way of creating memories of a given group's loyalty (or betrayal) in times of conflict. In this case, they honored the Kenites by linking their story to that of Moses's illustrious father-in-law, a Midianite who plays a pivotal role in Israel's emergence as a nation as it made its way from Egypt to the Promised Land.

\section{FELLOW TRAVELERS}

The book of Exodus presents Moses ultimately sending his father-in-law away to "his own country" (Exod. I 8:27). ${ }^{18}$ The only ones who remain with Israel are Jethro's daughter and the two sons she bore to Moses. Yet as the narrative progresses, we get a different view: In the book of Numbers, this man - now called "Hobab, son of Reuel the Midianite" (see Judg. 4:I I) - is still with Israel as they are camped at Sinai. Moses now implores him to accompany Israel as they voyage to their new homeland: "Come with us, and we will be sure to show you favor, for Yhwh has declared favor toward Israel" (Num. I0:29). The offer is initially declined: "I will not go [with you], but will go instead to my own country and native land" (cf. Exod. I 8:27). Moses doesn't allow this to be the final word: "Please do not abandon us, for you know where we should camp in the wilderness and can be our guide (lit. eyes). If you come with us, we will be

see Martin Buber, Moses: The Revelation and the Covenant (Amherst, NY: Humanity Books, I988), 94. Cf. Ex. Rab. 27.6; Midr. Ag. Ex. I 8.6. A rabbinic tradition has Jethro dodging conscription from the Amalekite military courts and then becoming a foe of the Amalekite nation (Midr. Samuel I I.2).

${ }^{18}$ The line in Exodus I 8:27 was perhaps originally connected to the first words of I 8:I 3 . 
sure to extend the same favor that Yhwh grants us!” (Num. I0:30-32). The petition implies that Hobab's clan will inherit a portion of the Promised Land.

The following lines (Num. 10:33-36) describe the departure, with the cloud of Yhwh and the ark of Yhwh's covenant guiding Israel to its encampments. Since Hobab's response is not provided, many scholars assume that something has been deleted; however, the account likely presupposes the statements in Judges, which affirm that the descendants of Moses's father-in-law, now identified explicitly as "Kenites," did indeed become fellow travelers with Israel. This is the only instance in which an outside group joins the nation after it leaves Egypt. ${ }^{19}$ During the conquest of Canaan, the Kenites fought alongside the tribe of Judah and inherited a portion of the land with them. Accordingly, the account in Numbers implies that Hobab acquiesced, taking his place near the cloud and ark at the front of the camp. ${ }^{20}$

The promise Moses makes to Hobab sounds like an invitation to join the Israelite fold. As Jacob Milgrom pointed out, the language is covenantal and as such may be compared to the description of the treaty sacrifices and commensality between Jethro, Aaron, and the elders of Israel in Exodus I 8. ${ }^{21}$ As with Rahab, the favor Hobab shows Israel is eventually repaid to his descendants in the form of rights to settle in the Negeb of Arad "among the people." The directly preceding lines (Judg. I:IO-I 5) tell how the Calebite clan came to possess a prized portion of the Promised Land, also in the Negeb, as a reward for the martial valor of its eponymous ancestor. ${ }^{22}$

By creating memories of early encounters with outsiders, the biblical scribes made a case for a political posture toward the group in question. As we saw in Part I, many of these memories relate to the nation's future

19 The Rahab clan and the Gibeonites become members of the nation after it enters Canaan. There are hints dropped throughout the narrative that the nation was a "mixed multitude" (see, e.g., Exod. I 2:3 8; Num. I I:4), but we probably should assume that this refers to the nation's population as it left Egypt.

20 The placement of the episode at this point in the narrative is undoubtedly related to the description of the guidance provided by the ark and the cloud. On the compositional issues of the passage, see Germany, Exodus-Conquest Narrative, I94-I97.

${ }^{21}$ Jacob Milgrom, Numbers: The JPS Torah Commentary (Philadelphia: Jewish Publication Society, I990), 79. Notably, the very next chapter contains a reference to a contingency of newcomers ( $w^{e} h \bar{a}$ 'sapsup, lit. those who were added) that "were in [Israel's] midst" (Num. II:4). On $w^{e} h \bar{a}$ 'sapsup, compare the possible qtltl noun form 'érebrab in Exodus I 2:38.

${ }^{22}$ I treat this passage in David, King of Israel, I 86-I 89. 
neighbors; in this case, the memory relates to a group that became fellow travelers with the nation. All these texts are not easily assigned to the conventional documentary sources, especially if they are assumed to have originated independently of each other. ${ }^{23}$ The memories betray not only knowledge of each other; they also directly engage and challenge each other, exemplifying the combative character of war commemoration in which rival groups negotiate belonging and status in their communities by constructing competing memories of wartime loyalty and betrayal.

Thus, we see how a group of biblical scribes, by means of an extended history of supplementation, affirmed a special relationship with the Kenites by linking them to Moses's own in-laws. ${ }^{24}$ Writing in the late Persian and Hellenistic periods, the authors of Chronicles grafted the Kenites onto Israel's family tree. Instead of joining Israel along the way, the Kenites are, according to this work, descendants of the illustrious Calebites, related to the devout Rechabites, and include scribal families who lived in the town of Jabez (I Chron. 2:55). ${ }^{25}$ Rejecting this positive posture, other scribes cast hostile aspersions on this people, as we observed in both the promise to Abraham and the curse of Balaam. Here again, we see how biblical war commemoration is not only a decentralized discourse but also a relentlessly disputatious one.

\section{DEVOTION TO A DEITY}

According to a line of rabbinic interpretation, scripture refers to Jethro as "Hobab" after his visit to Moses because he "embraced" Israel's God. Since the place where he appeared is called the "Mountain of God," Jethro must have undergone a change of heart upon learning about Israel's experience in Egypt. The biblical text states that "Jethro rejoiced for all the good that Yhwh had done for Israel in delivering them from the Egyptians" (Exod. I 8:9). Concluding his blessing, he makes a broad declaration: "Now I know that Yhwh is greater than all gods" (Exod. I8:IO-II). Thereafter, he performs sacrifices and breaks bread with Moses, Aaron, and the elders of Israel "in the presence of God." These biblical statements prompted the rabbis to search for other clues showing

${ }^{23}$ See the discussion in Parts I and II.

${ }^{24}$ These texts correspond to the three fundamental stages of Israel's history in the exodusconquest narrative: Moses's flight followed by the exodus, the nation's wanderings in the wilderness, and the conquest of the land.

25 Shemaryahu Talmon, "These Are the Kenites Who Come from the Father of the House of Rechab," Eretz Israel, 5 (I959), I I I-I I 3 [in Hebrew]. 
that he underwent the formal rites of conversion. They discovered a deeper meaning in the root of the Hebrew word describing Jethro's reaction ("and he rejoiced," wayyihad), taking it to mean either that he circumcised himself with a "sharp" knife or that he proclaimed the "oneness" of Israel's deity. ${ }^{26}$

Many modern scholars have adopted the opposite approach: instead of Jethro embracing Israel's God, Israel embraced Jethro's God. Beginning in the mid-nineteenth century and persisting to the present, scholars have invoked these texts in support of the so-called Midianite-Kenite Hypothesis. Jethro's affirmation, "Now I know that Yhwh is greater than all gods," is taken to mean that this Midianite-Kenite priest is asserting that the deity he had long venerated and served (i.e., Yhwh) was indeed the greatest of all gods. This interpretation of the biblical text is highly problematic, yet some inscriptional evidence from Egypt does suggest that the veneration of Yhwh originated among proto-Arabian tribes east and west of the Arabah and the Gulf of Aqaba. ${ }^{27}$ The matter is beyond the scope of our study; it suffices for the present to recognize that the assumption of connection between the Kenites and Midianites rests on late supplements to the book of Judges and has little to do with a historical relationship between these groups.

This double-sided history of interpretation - with the rabbis, on the one side, reading the account as a description of Jethro's conversion, and modern scholars, on the other side, constructing theories like the Midianite-Kenite Hypothesis - is a result of the manner in which these texts negotiate matters of national belonging.

In the case of Rahab, we saw in Part III how scribes supplemented her deeds with words acclaiming the superiority of Israel's national deity. With respect to Jethro, notice the supplementary character of the passage (Exod. I8:8-II) in which this figure rejoices over the favor that

${ }^{26}$ See, respectively, b. San. 94a and Yal. Shim. 268.

${ }^{27}$ Originally proposed by Friedrich Wilhelm Ghillany in $\mathrm{I} 862$, the hypothesis has won the support of a long list of important scholars: Eduard Meyer, Bernhard Stade, Karl Budde, Thomas Kelly Cheyne, Henry Preserved Smith, and later Gerhard von Rad, Martin Noth, Harold Rowley, Manfred Weippert, and Moshe Weinfeld. See, most recently, Joseph Blenkinsopp, "The Midianite-Kenite Hypothesis Revisited and the Origins of Judah," Journal for the Study of the Old Testament, 33 (2008), I3I-I53; Nadav Na'aman, "The Kenite Hypotheses in Light of the Excavations at Horvat Uzza" in Gilda Bartolini and Maria G. Briga (eds.), Not Only History: Proceedings of the Conference in Honor of Mario Liverani (Winona Lake: Eisenbrauns, 20I6), I7I-I 82; Juan Manuel Tebes, "The Southern Home of YHWH and Pre-Priestly Patriarchal/ Exodus Traditions from a Southern Perspective," Biblica, 99 (20I8), I66-I88. 
Yhwh showed the nation and then declares this deity to be greater than all others. ${ }^{28}$ The rest of the account uses the generic term for god ('elōhim), while only this passage refers to Yhwh. ${ }^{29}$ This passage has much in common with Numbers I0:29-32, where Moses petitions his father-inlaw to accompany them to the Promised Land. (For example, both texts highlight the "good" Yhwh does for Israel.) The addition of Exodus I 8:8-II serves a much wider narrative arc, yet its author apparently deemed this to be the best place to present Jethro acknowledging Yhwh's supremacy. Another large supplement to the chapter goes a step further, presenting Jethro as one who not only acknowledges that Yhwh is greater than all gods but also recognizes the importance of divine laws and statutes. ${ }^{30}$

Thus, we again see how biblical scribes added theological words to political deeds, pointing to a particular deity as both the emblem and the source of the nation's unity. Israel may consist of rival communities and regions, each with their own history and tradition; nevertheless, they can be one people if they remain devoted to one god and his one law.

\section{JAEL AS A KENITE AND A JEW}

The various strands of our study coalesce in the character of Jael. Like Rahab, Jael is an archetype of the marginalized outsider. As a woman, she is left back in her tent while the men take part in a military campaign. As a tent-dwelling nomad, she pursues an existence on the periphery of society. And as a member of the Kenites, her allegiance is in doubt. She

${ }^{28}$ The rabbis connected Jethro's acclamation to that of Rahab by claiming that Jethro, as a pagan priest, knew that Yhwh was the greatest, because he had "fornicated" (a term often used to describe illicit worship) with all deities on earth, just as Rahab had slept with all the men of the land and witnessed how Yhwh's power had made them impotent (Mek. Rab. Ish., Amalek 3).

${ }^{29}$ Notice the abrupt switch in verse I 2; verse $\mathrm{Ib}$ reflects the influence of verses 8-I I.

30 The supplement is found in Exodus I 8:13-26, where Jethro advises Moses to establish a juridical system. Moses originally sends him away "the next day" following the commensality (v. 27), just as Laban leaves on the morning after a covenantal feast (Gen. 3 I:54, 32:I-2). Moreover, Jethro doesn't seem to enter the camp, as seen already in Midr. Ag. Ex. I 8.6. The supplement likely takes its cue from Moses's complaint in Deuteronomy I:9-I 8, which would explain the passage's Deuteronomistic language. By attributing a juridical system to Jethro, the author emphasizes his special solicitude for Moses's personal welfare, a prominent feature of these texts. In Part II, we saw how biblical scribes augmented an earlier emphasis on kinship by shifting attention to Yhwh and his law as the focal point of the nation's unity. 
surmounts the obstacles presented by her identity not by circumventing them, but rather by wielding them to her advantage.

The depiction of the murder plays on markers of her identity as a Kenite woman: just as she transforms her personal domestic confines into a battlefield, the milk she feeds Sisera and the tent peg and hammer she brandishes as weapons fuse the characteristic features of her nomadic people who dwell in tents, herd flocks, and forge metal objects. ${ }^{3 \mathrm{I}} \mathrm{We}$ noted the Kenites' violent associations in a number of biblical texts, beginning with Cain's murder of his brother, and these associations may make themselves felt in the characterization of Jael. If so, the author would be introducing a twist on the Kenites' putative capacity for violence: Jael directs this aggression not against Israel, but against the nation's enemies.

Because Jael courageously and creatively exploits her distinctive qualities, she is honored in the Song of Deborah with the remarkable approbation: "Most blessed of women is Jael, the wife of Heber the Kenite. Of tent-dwelling women she is most blessed" (Judg. 5:24). ${ }^{32}$ For early readers, this glowing praise provoked questions that are taken up in rabbinic sources: Does Jael deserve more praise than Deborah? Is she more blessed than the nation's greatest matriarchs such as Sarah, Rebekah, Rachel and Leah, who were also tent dwellers (Gen. I8:9, 24:67, 3 I:33)? Although one should perhaps not make too much of the song's hyperbole, the text contains clues as to what makes her case so special: she is not an Israelite, yet she risks her life on the behalf of the nation and thereby violates the political allegiances of her husband (Judg. 4:I7). Responding to these questions, Rabbi Eliezer points out that the matriarchs of Genesis deserve praise since they gave birth to Israel, yet the nation (their children) would have ceased to exist had it not been for Jael's valorous deeds. ${ }^{33}$

A strophe from the Song of Deborah begins "in the days of Shamgar ben Anat, in the days of Jael." Throughout the book of Judges, the expression "in the days of" consistently denotes the discrete era in

${ }^{31}$ The hammer is the traditional symbol of the smith in many cultures. Various biblical texts locate the Kenites deep in the southern Negev, which would place them in a region rich in metals and home to much mining and minting activity in antiquity. On the marginal identity of metalworkers in ancient Mediterranean, see Sandra Blakely, Myth, Ritual and Metallurgy in Ancient Greece and Recent Africa (Cambridge: Cambridge University Press, 2006). Note, likewise, the place-name Harosheth-Hagoyim (lit. smith of the nations) (Judg. 4:2, I3, I6).

32 Heber here seems to be denigrated by being remembered only as her husband.

33 Gen. Rab. 48. On this tension in Jewish identity between yichus (birth, descent, genealogy) and zechut (merit, conduct), see Wright, David, King of Israel, $8_{3}-84$. 
which a particular Israelite deliverer/judge governs. Likewise, the story of Ruth begins "in the days when the judges governed." On the basis of this text, Ruth Rabbah and other rabbinic sources identify Jael as not only an Israelite but also as a full-fledged "judge" like Deborah and Gideon.

When the rabbis defend Jael's identity as an Israelite, they do so by arguing that she complied closely with Jewish law: if she "went out" of her tent to greet Sisera, it's because the war was a milhemet mitzvah (an obligatory war), when "all go out to war, even the groom leaves his chamber and the bride her chuppah"). An Aramaic translation (the Targum Yerushalmi) inserts right before Judges 5:26 that Jael "fulfilled that which is written in the Teaching of Moses: 'Weaponry of a man shall not be on a woman neither shall a man wear a woman's garment.' Therefore she reached for the tent peg." Here the translator refers to Deuteronomy 22:5 and the prohibition of "Lo Yilbash," which forbids women to bear the "weapons of men" (kelî-gever). If Jael used milk, a peg, and a hammer, instead of conventional weaponry, it must have been, according to this line of reasoning, because she strives to comport herself in keeping with the Torah. ${ }^{34}$

In these ways, Jewish interpreters added a new dimension to the societal expectations of women in wartime that we surveyed in Chapter I3. Their creative interpretations illustrate what we have repeatedly observed about biblical war commemoration - namely, that it gradually assumed a more pronounced theological disposition. In Part II, we witnessed how scribes expanded a narrative about kinship by affirming the deity and a body of divine, written law as the foundation of national unity and belonging. In the stories of Jael and the Kenites, the principles of kinship and divine law coalesce, and while this coalescence reaches a zenith in the postbiblical imagination, it's on display already in the work of the anonymous scribes who connected Jael and her people to the remarkable stories of Moses's father-in-law.

34 The heroine of the (nonrabbinic) book of Judith severs Holofernes's head with a sword (Jth. I3:6-8). The rabbinic identification of Jael as a Jew is predicated on adherence to Jewish laws that adopt a binary gender classification (also known as gender binarism). Jael is accordingly a Jew inasmuch as she knows that she must not behave like a Jewish man. 